\title{
Developing Learning Methods of Indonesian as a Foreign Language
}

I Nyoman Suparsa ${ }^{\text {; }}$ Ida Bagus Nyoman Mantra b; Ida Ayu Made Sri Widiastuti c;
Article history: Received 11 January 2017; Accepted in revised form 5 July 2017; Approved 10 August 2017;
Available online 30 August 2017




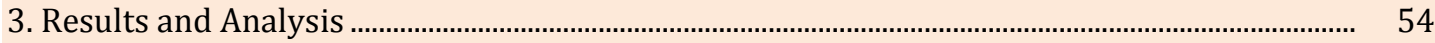

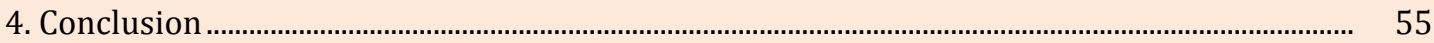

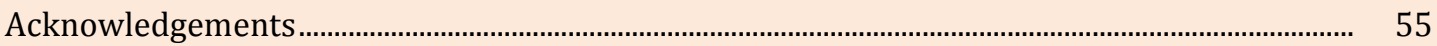

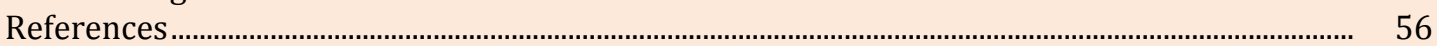

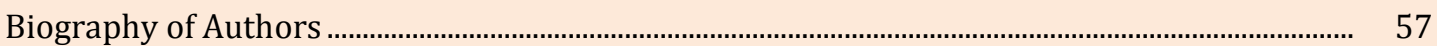

\section{Introduction}

Language is a medium of communication among people throughout the world. Having a good mastery of language, people can communicate effectively to share a wide range of meanings, ideas, emotions, feelings and solve a variety of problems in life. It is unimaginable how people could express their complex and diverse ideas, meanings, feelings, and emotions without a language. In order to increase the intensity and quality of relationships, communication, interaction, business transactions, trade and diplomacy with the nations of the world, Indonesian was considered to be one of the most important languages to be mastered by most people all over the world.

Therefore some universities recently offered the students to learn to be Indonesian teachers to teach foreigners. This was done so that the quality of educators can be improved in the view of the global development which is marked by the rapid development of science and technology. The era of globalization and internationalization provides a vast opportunity for this nation to develop itself (Mantra, 2017). This situation is very beneficial for Indonesian teachers for foreign speakers. In the beginning, Indonesian language teaching for foreign speakers is only as a form of service for some learners coming from abroad who want to learn Indonesian. However, nowadays there is a growing desire of many people to learn Indonesian due to the strategic geographical location of Indonesia which rich culture, and a number of foreign companies that invested in Indonesia.

Moreover, in line with the development of free market and development of Asian Economic Community, three is an increasing interest in Indonesian language. Additionally, the Indonesian government is planning to assess all foreign workers' ability in Indonesian language. An ideal language assessment should be done authentically (Ariev, 2005; Gulikers, Bastiaens, \& Kirschner, 2004) and various models of assessment should be administered (Lumadi, 2013). Therefore, in essence, the teaching of Indonesian language, Fathurrohman and Sutikno (2007: 8) states that learning is essentially a transactional process of mutual communication between teachers and students and among students with each other to achieve the objectives that have been established effectively and efficiently (Hussain, Adeeb, Aslam, 2011). The transactional communication that is essentially on is delivering various ideas, ideas, messages is a form of communication that can be accepted, understood and agreed by the parties concerned and involved in the learning process.

In the learning process, a teacher who is an agent of change has a strategic key position in creating a conducive learning environment to engage the students in learning. To that end, the teachers are required capable and skillful in playing a number of roles simultaneously (Maba, 2017; Wahyudi, et al., 2002). As an agent of change, a teacher has a dominant role and determinant to the success of the learning process which essentially is the communication process. The learning process is a very complex and multi-dimensional communication process that is influenced by many factors, both internal and external factors. Several factors are often obstacles or barriers to the process of communication, such as psychological barriers such as interests, talents, attitudes, intelligence, knowledge, and motivation (Maba, 2017; Sadiman, et al., 2005: 11). As a strategic central figure, a teacher must be able to select, sort out, set various strategies, methods and techniques of learning that can support and encourage active, creative, productive, and efficient learning (Vienna Sanjaya, 2006).

In accordance with the description above, it is clearly illustrated that the occurrence of meaningful communication is the core and essence of language learning. Therefore, success in the process of learning Language partially is clearly indicated and reflected from the ability 
of teachers in creating, building and developing various patterns of communication in the class both the dimension of transactional and interpersonal. Dulay, et al. (1984: 20) argues that in the process of language teaching and learning is known that there are three patterns of communication: communication in one direction, restricted two-way communication and the multi-directional communication (Mantra, 2017).

One-way communication generally occurs between teachers and students in a classical manner when teachers use lecture methods and students are actively listening to it, or students perform reading activities. In the process of language learning, the quantity and intensity of one-way communication must be consciously reduced, but the quality needs to be improved because it is not conducive and even tends to shut down the active and creative participation of students in learning and communicating exercises. In the two-way communication is limited, the teacher has started to activate and involve students in interacting. Competence-based language learning, essentially manifested in language teaching and learning for specific purposes, according to Dubin and Olshtain (1992) and Krahnke (1987), should be a selective blend of several syllabuses such as the contents-based syllabus, Tasks-based syllabus, skill-based syllabus and syllabus nosi and functional (notional-functional syllabus). On this foundation and guideline of such a syllabus, teachers are required to be always active and skilled in preparing different types of activities and communicative tasks for the active and creative involvement of all students in the teaching and learning process. All activities and teaching materials and tasks are designed and prepared in such a way by accessing a variety of learning resources so as to be challenging, interesting and fun for students.

According to Richards and Rodgers (1986) syllabus, appropriate classroom exercises and activities will sustain the achievement of teaching objectives. Language learning based on the communicative competence unlimited number, type, and variation. All teaching materials, exercises, assignments and learning activities should be designed so that it enables the interaction and communication during the process of teaching and learning among students. In designing various exercises and communicative activities, teachers need to consider differences between students in various ways, such as communication needs, motivation, and attitudes (Littlewood, 1986). Furthermore, Littlewood explained that teaching materials, tasks, and various communicative activities must be in accordance with the needs of students, certainly no question. Teaching and learning for specific purposes clearly have implications for the selection of instructional materials that must be tailored to the needs of the students. In addition, the various exercises, tasks, and communicative activities must be interesting, challenging and fun so as to increase motivation and change the attitude of students.

\section{Research Method}

The research made use of a Research and Development Design investigating the development of learning methods of Indonesian as a foreign language. The development of teaching materials of learning methods of Indonesian as a foreign language was carried out in six steps of sequence, namely: (1) analyze the relevant book about models of teaching materials of learning methods of Indonesian as a foreign language, (2) planning competence and The purpose of each chapter or section, (3) to make the initial draft of teaching material model of learning methods of Indonesian as a foreign language, (4) to test the initial draft of teaching material model of learning methods of Indonesian as a foreign language on a limited number of subjects; (5) revise the initial draft Model of teaching materials based on try out results, and (6) re-examine the revised draft based on the results of the first trial.

Based on the steps Research and Development ( $R \& D$ ) above, the study begins by conducting field research to collect data on the model of teaching materials of learning methods of Indonesian as a foreign language. After the data collected, research activity continued by analyzing the teaching material model of learning methods of Indonesian as a foreign language so that it was found the weaknesses and strengths of the teaching materials

Suparsa, I. N., Mantra, I. B. N., \& Widiastuti, I. A. M. S. (2017). Developing learning methods of Indonesian as a foreign language. International Journal of Social Sciences and Humanities, 1(2), 51 57. https://doi.org/10.29332/ijssh.v1n2.41 
model of learning methods of Indonesian as a foreign language. Then, based on the principles of learning material model development, the research continued with the making of the initial draft of teaching material model of learning methods of Indonesian as a foreign language.

Research in the first year begins by collecting the teaching material model of learning methods of Indonesian as a foreign language that has been used in various institutions in Bal. Following activities was to analyze the teaching material model Learning Method of learning methods of Indonesian as a foreign language based on the guidance of making teaching materials so that were found weakness and strength from the teaching material model of learning methods of Indonesian as a foreign language that already exists. Furthermore, based on the results of the analysis developed the initial draft of teaching materials model of learning methods of Indonesian as a foreign language followed by field trials. This secondyear research was a very crucial activity because the trial of a teaching material model of learning methods of Indonesian as a foreign language is absolutely necessary so that the teaching material model of learning methods of Indonesian as a foreign language is really meant for the development of student's knowledge. In this case, the learning material model of learning methods of Indonesian as a foreign language is expected to be able to measure the true language skill.

\section{Results and Analysis}

Based on the results of the research conducted in the development of teaching materials for learning methods of Indonesian as a foreign language which began by examining various libraries related to learning methods of Indonesian as a foreign language and also based on various discussions and interviews with language teachers in Bali and outside Bali. Results as to the topics of learning methods of Indonesian as a foreign language can be developed into 9 main topics: (1) The essence and scope of Indonesian language teaching for foreigners, (2) Subject to the importance of Indonesian language for foreigners, (3) Indonesian Language as a Foreign Language, (4) Type of Indonesian learning approach, (5) learning methods of Indonesian as a foreign language, (6) Strategy and skill-based learning of Indonesian as a foreign language, (7) Development of syllabus, (8) Development of Lesson Plan, (9) Development of learning materials.

In this study also found that the achievement of the purpose and objectives of the Indonesian language teaching to foreign language speakers is affected by three components. The three components are learners, learning materials, and learning process. The relationship of these three components is so important that it will determine the learning outcomes. 1) Learning is a component that is very prominent existence because of the characteristics and the role of the learner can be seen from a) motivation, b) the purpose of learning, c) talent, d) the characteristics of personal, e) how / learning strategies, f) cognitive ability, g) Knowledge / ability. 2) Organizer. In this case, organizers need to understand the characteristics and role of learners because each individual has unique and different characteristics. 3) Learning process. In the process of learning a good understanding must be raised when preparing teaching materials.

Discussion of the results of this study in the form of Indonesian learning method for foreign speakers which contains nine units of learning is considered to have adequate material coverage for learning methods in the course of Language Education and Indonesian Literature. The material presented in the learning method module provides sufficient wards for prospective teachers of learning methods of Indonesian as a foreign language since this module departs from the general nature of learning methods of Indonesian as a foreign language and the development of the syllabus, lesson plan and also the development of teaching materials. So prospective teachers are not only good at choosing learning methods and strategies, they should also be able to make syllabus, lesson plans, and teaching materials.

This section discusses the subject of the importance of learning Indonesian for foreign speakers. Where Indonesian language learning for foreign speakers is intended to introduce 
the Indonesian language to foreign speakers for various purposes, both teaching, and practical communication. In addition, learning Indonesian as a foreign language, as well as other languages as a foreign language is intended to provide written and oral mastery to the learners. This implies that they are supposed to be able to use Indonesian to speak fluently and at the same time be able to understand the languages spoken by native speakers.

In relation to the purpose and objectives of learning methods of Indonesian as a foreign language and the skills expected of every learner, as described above, learning methods of Indonesian as a foreign language has still a lot of constraints, among them the lack of standard curriculum and the lack of varied teaching materials. Factually speaking about the curriculum of learning, until now there is no certain curriculum that is made the standard curriculum. Therefore, education providers have the freedom to develop their own curriculum. In its compilation, the curriculum standards used are based on the purpose of accommodating various developments in language use.

The teaching methods of Indonesian for foreign speakers were developed based on a communicative approach that aims to Create competence communicative of the students. The main characteristic of the communicative approach is the existence of two closely interrelated activities, namely the existence of communicative activities and social interaction activities. Functional communicative activities consist of four things, namely: (a) processing information, (b) to share and process information, (c) share information with limited cooperation, and (d) share information with unlimited cooperation. Social interaction activities composed top six things, namely: (a) improvisation, (b) various simulations, (c) dialogue and a role play, (d) sessions of conversations, (e) discussion, and (f) debate.

Selection of teaching materials and learning media is closely related to the development aligned with the syllabus, in which there are a standard and basic competency, subject matter, learning experiences, methods, evaluation, and resources. In harmony with the development of the syllabus of learning the material to be developed, it should still consider the achievement of competence and basic competences standards, conformity with the subject matter being taught, supporting the learning experience, the accuracy of methods and media and in accordance with the indicators to develop the assessment.

\section{Conclusion}

The research related to the development of teaching materials of learning methods of Indonesian as a foreign language was conducted with the aim that students taking courses in learning methods of Indonesian as a foreign language to develop their academic potential to become a professional language teacher. These materials were compiled based on the needs analysis. The interim results of the study in the first year were in the forms of the draft of learning methods of Indonesian as a foreign language. This draft has been explored and developed further by doing a series of the trial. The analysis of the material is absolutely necessary using the rubric for assessing the suitability of teaching materials so that the content and format of these materials in accordance with the needs of the learner. Revamping the format and the development was conducted to ensure the teaching methods were more meaningful and contextual. To sum up, based on the result of the trial, these learning materials have been considered to sufficient and effective to teach the students to comprehend various aspects of learning methods of Indonesian as a foreign language.

\section{Acknowledgement}

The authors would like to express his profound gratitude to all educators, teachers, and researchers for their help in conducting and writing this study. Deep sincere gratitude also is dedicated to all friends for their support, their contribution, and their valuable input during the writing of this paper. Sincere gratitude also goes to the editors who have reviewed and approved this article to be published.

Suparsa, I. N., Mantra, I. B. N., \& Widiastuti, I. A. M. S. (2017). Developing learning methods of Indonesian as a foreign language. International Journal of Social Sciences and Humanities, 1(2), 51 57. https://doi.org/10.29332/ijssh.v1n2.41 


\section{References}

Adetunji, A. T., Adetunji, A. V., Adeleke, E. O., \& Madubuike, S. C. (2017). Deregulation: The Effect of Marketled Approach to Nigerian Universities Management. International Journal of Social Sciences and Humanities (IJSSH), 1(1), 1-8.

Amerta, I. M. S. (2017). The Role of Tourism Stakeholders at Jasri Tourism Village Development, Karangasem Regency. International Journal of Social Sciences and Humanities (IJSSH), 1(2), 20-28.

Ariev, P.R. 2005. A Theoretical Model for the Authentic Assessment of Teaching. Practical Assessment, Research \& Evaluation, 10(2), 1-11

Astawa, I. N., Mantra, I. B. N., \& Widiastuti, I. A. M. S. (2017). Developing Communicative English Language Tests for Tourism Vocational High School Students. International Journal of Social Sciences and Humanities (IJSSH), 1(2), 58-64.

Berti, Segendra. 2014. Learning and Learning Bahasa Indonesia. Semarang: Publisher: Linggayoni Publishing

Bogdan, Robert, C \& Biklen, Sari Knopp. 1982. Qualitative Research for Education. Massachusetts: Allyn and Baco, Inc

Brown, Douglas H. 2004. Language Assessment: Principles and Classroom Practices. New York:

Cedeño, M. L. D., Arteaga, M. G. D., Pérez, A. V., \& Arteaga, M. L. D. (2017). Regulatory Framework for Renewable Energy Sources in Ecuador Case Study Province of Manabí. International Journal of Social Sciences and Humanities (IJSSH), 1(2), 29-42.

Dick, W. and Carrey, L. 1985. The Systematic Design of Instruction. Illinois: Scoot., Foreman, and Company.

Dubin, Fraida dan Olshtains, Elite. 1992. Course Design: Developing Programs and Materials for Language Learning. Cambridge: Cambridge University Press.

Fathurrohman, Pupuh dan Sutikno, Sobry. Teaching and Learning Strategies. Bandung: PT. Refika Aditama

Gulikers, J.T.M, Bastiaens, T.J., \& Kirschner, P.A. (2004). A five-dimensional framework for authentic assessment. Educational Technology Research and Development, 52(3), 67-86

Hussain, Z., Adeeb, A., Aslam, H.D. 2011. Curriculum Implementation and Feedback Mechanism at Secondary School Level in Punjab Pakistan. International Journal of Learning \& Development, 1(2), 92-98

Krahnke, Karl. 1987. Approaches to Syllabus Design for Foreign Language Teaching. London: Prentice-Hall International, Ltd

Littlewood, William T. 1986. Learning Foreign and Second Language. London: Cambridge University Press.

Lumadi, M.W. 2013. Challenges besetting teachers in classroom assessment: an exploratory perspective. Journal of Social Science, 34(3), 211-221

Maba, W. (2017). Teacher's Perception on the Implementation of the Assessment Process in 2013 Curriculum. International Journal of Social Sciences and Humanities (IJSSH), 1(2), 1-9.

Maba, W., \& Mantra, I. B. N. (2017). An Analysis of Assessment Models Employed by The Indonesian Elementary School Teachers. International Journal of Social Sciences and Humanities (IJSSH), 1(1), 3945.

Maba, Wayan. 2017. International Journal of Social Sciences and Humanities. Teachers' Perception on the Implementation of the Assessment Process in 2013 Curriculum. Vol. 1 No. 2

Maba, Wayan. 2017. Teachers' sustainable professional Development Through Classroom Action Research. International Journal of Research in Social Sciences.Vol. 7

Maba, Wayan. 2017. The Implementation of Education National Standard in the Instrument of School Accreditation of Bali Province Education Authority. International Research Journal of Engineering, IT \& Scientific Research (IRJEIS). Vol. 3 Issue 4

Mantra, I.B.N. 2017. Promoting Primary School Teachers' Competence through Dynamic Interactive Workshop and Partnership International Journal of Linguistics, Language, and Culture (IJLLC)Vol. 3, No. 1

Pandjaitan, Mutiara O. 2003. Classroom Assessment with Portfolio. A Seminar paper presented at Indonesia University of Education 2003

Pearson Education.

Sardiman. 2001. Interaction Motivation Learning Teaching. Jakarta: PT Raja Grafindo Persada

Suparsa, I. N., Mantra, I. B. N., \& Widiastuti, I. A. M. S. (2017). Developing Learning Methods of Indonesian as a Foreign Language. International Journal of Social Sciences and Humanities (IJSSH), 1(2), 51-57.

Suryasa, I. W., Prayoga, I. G. P. A., \& Werdistira, I. W. A. (2017). An Analysis of Students' Motivation Toward English Learning As Second Language Among Students In Pritchard English Academy (PEACE). International Journal of Social Sciences and Humanities (IJSSH), 1(2), 43-50.

Suyitno, Imam. 2007. Development of Indonesian Language Learning Material for Foreign Speakers (BIPA) based on Learning Needs Analysis Result. Wacana Vol. 9 No. 1, pp 62-78 
Wina, Sanjaya. 2006. The strategy of Learning-Oriented Standard Process of Education. Jakarta: Pernada Media

\section{Biography of Authors}

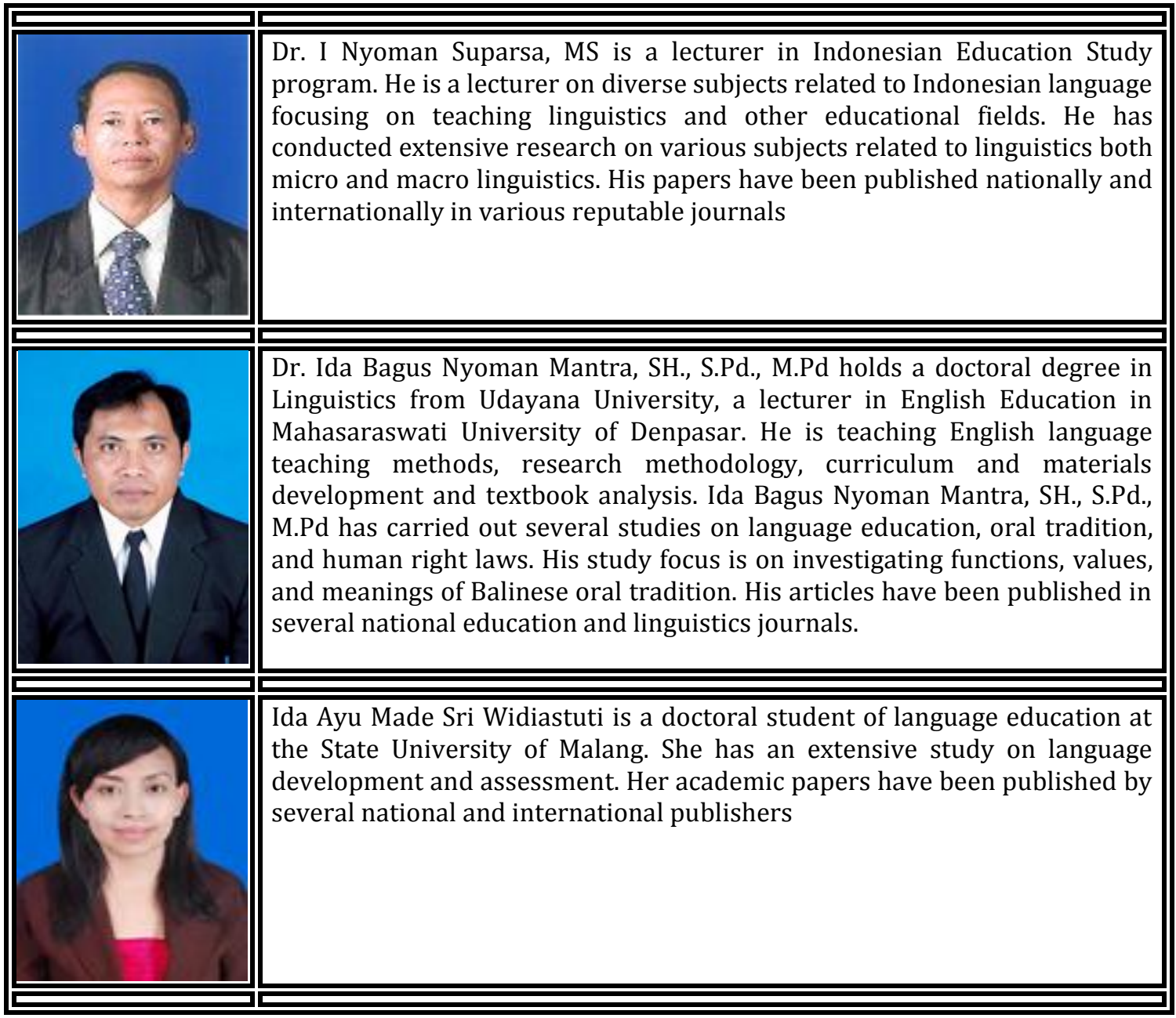

Suparsa, I. N., Mantra, I. B. N., \& Widiastuti, I. A. M. S. (2017). Developing learning methods of Indonesian as a foreign language. International Journal of Social Sciences and Humanities, 1(2), 51 - 